\title{
Analysis of the chemical composition of the lionfish Pterois volitans as a food strategy for its control
}

\author{
María Isabel Castro-González ${ }^{1}$, José Adán Caballero-Vázquez ${ }^{2}$ \\ Fernando M. Guerra-Infante ${ }^{3} \&$ Marcela López-Hurtado ${ }^{3}$ \\ ${ }^{1}$ Dirección de Nutrición, Instituto Nacional de Ciencias Médicas y Nutrición Salvador Zubirán \\ Tlalpan, Ciudad de México, México \\ ${ }^{2}$ Centro de Investigación Científica de Yucatán, Unidad de Ciencias del Agua, Laboratorio de Ecología \\ y Biodiversidad de Organismos Acuáticos, Cancún, Quintana Roo, México \\ ${ }^{3}$ Laboratorio de Inmunobiología Celular y Molecular, Instituto Nacional de Perinatología \\ Ciudad de México, México \\ Corresponding author: José Adán Caballero-Vázquez (adan07@gmail.com)
}

\begin{abstract}
The lionfish is the first invasive species that came to the western Atlantic region to establish itself as an ecological and economic threat to coral ecosystems and commercially important consumption species. Fifteen specimens were collected in Quintana Roo, Mexico, to analyze the chemical composition of the lionfish (Pterois volitans) as a strategy to promote its consumption by the population. They were gutted, filleted, homogenized and chemically analyzed. The analyzed LF had an energetic protein content of $103.89 \mathrm{kcal}_{100 \mathrm{~g}^{-1}}$ of the fillet (20.19\%) and a fat percentage of $2.56 \%$. The content of $\mathrm{P}, \mathrm{Ca}, \mathrm{Na}, \mathrm{K}$ and $\mathrm{Mg}$ were $174.15,26.09$, $81.47,339.73$ and $30.27 \mathrm{mg} 100 \mathrm{~g}^{-1}$, respectively. The most abundant essential amino acid was lysine (12.98 $\mathrm{g}$ $100 \mathrm{~g}^{-1}$ protein). The present work is important because it reports that the LF could be used as food with the right quantity and quality of protein, and its consumption would diminish its environmental impact.
\end{abstract}

Keywords: Pterois volitans; red lionfish; invading species; chemical composition; aquaculture

In 2002, the National Oceanic and Atmospheric Administration (NOAA) informed on the successful invasion of Pterois volitans (Linnaeus, 1758) and Pterois miles (Bennet, 1828) in the USA Atlantic coastal waters. These species belong to the family Scorpaenidae, known as lionfish, scorpionfish, red firefish, red lionfish or turkey fish (Barriche et al., 2013; Tsiamis et al., 2015). They are native to the IndoPacific Ocean seas, from Japan to New Zealand, and all austral islands from Indonesia, Micronesia and French Polynesia until Sumatra (Barriche et al., 2013). Currently, its presence is considered as one of the major ecological disasters of the last 20 years due to the negative ecological and economic impact it is causing. Until now, it has no predators. It is a carnivorous fish, feeding on more than 60 fish species (of both commercial and ecological relevance), crustaceans and mollusks on the sites where it has successfully established (Whitfield et al., 2002; Morris \& Akins, 2009; Schofield, 2010).
Its reproductive success and adaptation to different habitats of the Caribbean has been such that in less than 30 years it has expanded dramatically its distribution, which goes from New York to Bermuda's, the Gulf of Mexico and the Caribbean, and the coasts of Guatemala, Venezuela and Brazil (Ferreira et al., 2015; Arredondo-Chávez et al., 2016).

Among the strategies for Pterois volitans lionfish (LF) control, there is consumption. Different biotic and abiotic factors determine the fatty acid (FA) composition in fish tissues and organs. This information is useful for humans because fish consumption is associated with health benefits. The lionfish is a mild-tasting fish, and its edible portion has the appearance of white and lean fish. Its taste is milder than that of jurel, bonito or lebranche mullet, similar to the northern red snapper (Hernández-Matus \& Caballero-Vázquez, 2015). However, its consumption has been controversial because it is considered a potential health hazard, due to the presence of a toxin

Corresponding editor: Patricio Dantagnan 
known as ciguatera. A scientific study demonstrated that its consumption does not pose any health risk because the toxin is deactivated by cooking the fish (Wilcox \& Hixon, 2015). The LF poison is a protein toxin that becomes inactivated $30 \mathrm{~min}$ after the fish dies, and is located in the spines (not in the edible portion). With good filleting, it does not pose any risk as long as it is well-cooked (Wilcox \& Hixon, 2015). Because the muscle represents the most important edible portion of fish, the objective of this paper was to analyze the chemical composition of the LF muscle as part of one of the strategies to stimulate its consumption.

Fifteen LF specimens were captured with Hawaiian spears in the region of Akumal in Quintana Roo, Mexico $\left(20^{\circ} 25^{\prime} 00^{\prime} \mathrm{N}, 8^{\circ} 18^{\prime} 00^{\prime} \mathrm{W}\right)$, during the summer of 2015. Specimens were transported to the Centro de Investigación Científica de Yucatán A.C. (CICY) laboratory. The average standard length of the fish was $19.19 \mathrm{~cm}$ with a weight of $231.31 \mathrm{~g}$.

Once in the CICY laboratory, fishes were gutted, filleted, separating from the edible portion (fillets), the internal spines, and those of the fins, including the skin. Fillets were frozen and transported to the Instituto Nacional de Ciencias Médicas y Nutrición Salvador Zubirán in Mexico City, where they were thawed, ground and homogenized to obtain randomly $300 \mathrm{~g}$ of sample to perform the chemical analyses in triplicate. Samples were previously supplemented with $0.1 \%$ BHT $^{\mathrm{TM}}$ (Butil-hydroxytoluene (Santa Cruz Biotechnology, Inc. Dallas, Texas, USA), as an antioxidant.

Analyses of protein, ashes, moisture and ether extract were performed according to the Official Methods of Analysis, Association of Official Analytical Chemists International (AOAC, 2005). For protein (Auto digester FOSS TECATORTM, model auto 20. Distiller Kjeltec FOSS ${ }^{\mathrm{TM}}$, model 8400), method 988.05 was used; for moisture (Drying stove Ríos Rocha ${ }^{\mathrm{TM}}$, model HS-41), 934.01 method; for ashes (Muffle Thermolyne ${ }^{\mathrm{TM}}$, model FA 1740), $942.05 \mathrm{~m}$ the energetic value was calculated according to the guidelines of the User's Manual of the Parr Calorimetric apparatus. All samples were analyzed in duplicate. Phosphorus (P) content was determined with method N968.08(b) (AOAC, 2005), in a Beckman, Mod. Du70, spectrophotometer. Content of $\mathrm{Na}, \mathrm{Ca}, \mathrm{K}$ and $\mathrm{Mg}$ were determined, after digestion, in a microwave system with a Perkin Elmer/Anton-Parr Multiwave 3000 oven, and analyzed with atomic absorbance spectrophotometry in a Perkin Elmer, model Analyst 800 apparatus, according to methods 976.25 and 965.17 (AOAC 2005). Analyses were made in duplicate. Amino acids were identified and quantified in an HPLC equipment (Amino acid analyzer Sýkam ${ }^{\mathrm{TM}}$, model S4300, S2100, S5200 and
S7130. Waters Empower 3), method 994.12 (AOAC). Ether extraction was performed in Extractor Soxtec equipment FOSS ${ }^{\mathrm{TM}}$, model 2050.

Table 1 depicts the proximal composition of the LF. The chemical analysis indicated content $(\%)$ of moisture, ashes, and fats of 76.18, 1.07, 20.19 and $2.56 \%$, respectively. Neither carbohydrates nor crude fiber was detected. The energetic value was of 103.9 $\mathrm{kcal} 100 \mathrm{~g}^{-1}$ of the fillet. Inorganic elements found (mg $100 \mathrm{~g}^{-1}$ sample) were phosphorus (P), 174.15; calcium (Ca), 26.09; sodium $(\mathrm{Na}), 81.47$; potassium $(\mathrm{K})$, 339.73; and magnesium (Mg), 30.27.

Table 2 depicts the amino acids profile, divided in essential, non-essential and conditionally essential amino acids measured in grams per each $100 \mathrm{~g}$ of protein. The most abundant essential amino acid was lysine (12.98), followed by leucine (8.60), valine (4.57), threonine (4.42), isoleucine (4.28), phenylalanine (4.11), methionine (2.71), histidine (2.32) and tryptophan (0.98). Regarding non-essential amino acids, the most abundant were glutamic acid (18.14), followed by aspartic acid (9.39), alanine (4.17) and serine (3.43). Lastly, regarding conditionally essential amino acids, the most abundant was arginine (7.11), followed by glycine (4.53), proline (3.60), tyrosine (3.24) and cysteine (0.94).

Scarce information has been published until now on the chemical composition of the LF. Hoo et al. (2013) reported the content of minerals and heavy metals of fishes caught in Jamaica and Morris et al. (2011) reported the content of some fatty acids. The present study informs on the content of nutrients in the fillet of LF caught in the Mexican Caribbean as a first approach to its relevance as food.

We found that the protein concentration (20.19\%) in $100 \mathrm{~g}$ of fillet provides from 36 to $44 \%$ of the daily requirements of this nutrient for adult men and

Table 1. Chemical composition and inorganic elements of the fillet of the Caribbean lionfish Pterois volitans.

\begin{tabular}{|c|c|}
\hline Chemical composition & g $100 \mathrm{~g}^{-1}$ sample \\
\hline Moisture & $76.18 \pm 003$ \\
\hline Ashes & $1.07 \pm 005$ \\
\hline Protein & $20.19 \pm 010$ \\
\hline Ether extract (fat) & $2.56 \pm 012$ \\
\hline Energetic content kcal $100 \mathrm{~g}^{-1}$ sample & $103.89 \pm 0.15$ \\
\hline Energetic content kj $100^{-1} \mathrm{~g}$ sample & $434.25 \pm 061$ \\
\hline Inorganic elements & mg $100 \mathrm{~g}^{-1}$ sample \\
\hline Phosphorus (P) & 174.15 \\
\hline Calcium $(\mathrm{Ca})$ & 26.09 \\
\hline Sodium $(\mathrm{Na})$ & 81.47 \\
\hline Potassium (K) & 339.73 \\
\hline Magnesium (Mg) & 30.27 \\
\hline
\end{tabular}


Table 2. Amino acids in the fillet of the Caribbean lionfish.

\begin{tabular}{lc}
\hline Essential & $\mathrm{g} 100 \mathrm{~g}^{-1}$ of fillet \\
\hline Histidine & 2 \\
Isoleucine & 4 \\
Leucine & 8 \\
Lysine & 1 \\
Methionine & 2 \\
Phenylalanine & 4 \\
Threonine & 4 \\
Tryptophan & 0 \\
Valine & 4 \\
\hline Non-essential & \\
\hline Alanine & 4 \\
Aspartic acid & 9 \\
Serine & 3 \\
Glutamic acid & 18 \\
\hline Conditionally essential & \\
\hline Glycine & 4 \\
Proline & 3 \\
Cysteine & 0 \\
Tyrosine & 3 \\
Arginine & 7 \\
\hline &
\end{tabular}

women, and lies within the nutritional interval ( 0.2 to 25\%) referred for fish (Huss, 1995). The moisture content (\%) was similar to that reported by Castro et al. (2007) in 16 species of Mexican marine fish (from 75.5 to $79.8 \%$ ), and high when compared to commercially relevant species of Venezuela, like the tambaqui $(70.73 \%)$, lisa $(71.09 \%)$ and tilapia $(72.36 \%)$ (Izquierdo et al., 1999), and it is within the average interval for fish, according to Huss (1995), which is from 66 to $81 \%$.

Regarding the protein concentration in $100 \mathrm{~g}$ of lionfish fillet, it is higher than that of scorpionfish fish muscle $(15.91 \%)$ (Scorpaena plumieri), which is a species that belongs to the same taxonomic family as the lionfish (Kaya \& Kocatepe, 2014). Also, the ash content is similar in both fishes, whereas the energetic content was higher in the LF than in scorpionfish

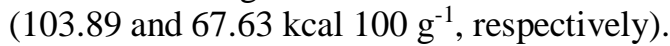

Fat is the nutrient with the highest variation due to biological factors like the physiological status, age, zone and time of capture, mainly (Huss, 1995; Castro et al., 2015). The LF depicts a fat content of $2.56 \%$ (Table 1) similar to that found by Kaya \& Kocatepe (2014) in scorpionfish $(0.20 \%)$. The LF can be considered a fish of low-fat content (2-4\% of fat) (Castro et al., 2007).

The phosphorus content (174.15 mg) was higher in the LF as compared to scorpionfish (33.28 mg) (Kaya $\&$ Kocatepe, 2014) and similar to the Mexican fishes: Caranx hippos (crevalle jack, jurel) and Sciaenops ocellatus (red drum, corvina) (Castro et al., 2015). According to Huss (1999), the P interval in fish ranges from 68 to $550 \mathrm{mg} 100 \mathrm{~g} \mathrm{~g}^{-1}$; thus, consumption of $100 \mathrm{~g}$ of fillet would supply $13.7 \%$ of the daily requirements (1.250 $\mathrm{m} \mathrm{P} \mathrm{d}^{-1}$ ) of this mineral in the human diet (U.S. DHHS \& USDA, 2015).

The calcium content $(26.09 \mathrm{mg})$ was low as reported by Hoo et al. (2013) and compared to the scorpionfish that shows 230 on $5 \mathrm{mg}$ in average (Kaya \& Kocatepe, 2014). Hence, this amount of calcium only contributes $2 \%$ to the daily requirements of men and women, according to the Dietary Guidelines for Americans 2015-2020 (U.S. DHHS \& USDA, 2015).

Other important components of the diet are sodium (Na) and potassium (K). Fish can have sodium intervals

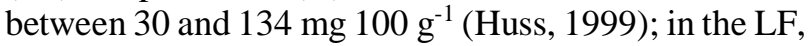
an average of $80 \mathrm{mg}$ was found, a concentration that is lower when compared to the scorpionfish with an average of $135 \mathrm{mg}$ (Kaya \& Kocatepe, 2014). For K, the concentration intervals range from 19 to $502 \mathrm{mg}$ $100 \mathrm{~g}^{-1}$. The LF showed considerable values of this mineral that were similar to those reported for the scorpionfish at relative levels of $350 \mathrm{mg}$ (Hoo et al., 2013; Kaya \& Kocatepe, 2014). For Mg, the reported intervals are between 4.5 and $452 \mathrm{mg} 100 \mathrm{~g}^{-1}$. The concentration in the LF is similar to that of the scorpionfish (34.62 mg $100 \mathrm{~g}^{-1}$ ) (Hoo et al., 2013; Kaya $\&$ Kocatepe, 2014). Therefore, the consumption of 100 $\mathrm{g}$ of LF muscle will supply $8.4 \%$ of the daily $\mathrm{Mg}$ requirements for adult men and women (U.S. DHHS \& USDA, 2015). Present work is the first study on the chemical composition and nutrient values in the LF of the Caribbean (western Atlantic). The levels obtained for these nutrients indicate that the LF has enough nutrients to be integrated into the human diet, containing significant amounts of all essential amino acids, mainly lysine. Frequent catching and consumption of the LF will allow controlling this invading species of the Mexican Caribbean, and bring about an economic improvement of the local communities that promote the consumption of this fish.

\section{REFERENCES}

Arredondo-Chávez, A.T., Sánchez-Jimenez, J.A., ÁvilaMorales, O.G., Torres-Chávez, P., Hererías-Diego, Y., Medina-Nava, M., Madrigal-Guridi, X., CamposMendoza, A., Domínguez-Domínguez, O. \& Caballero-Vázquez, J.A. 2016. Spatio-temporal variation in the diet composition of red lionfish, Pterois volitans (Actinopterygii: Scorpaeniformes: Scorpaenidae), in the Mexican Caribbean: insights into the ecological effect of the alien invasion. Acta Ichthyologica et Piscatoria, 46(3): 185-200. doi: 10.3750/Aip2016.46.3. 03. 
Association of Official Analytical Chemist (AOAC). 2005. Official methods of analysis. Association of Official Analytical Chemist, Gaithersbourg, 1234 pp.

Bariche, M., Torres, M. \& Azzurro, E. 2013. The presence of the invasive lionfish Pterois volitans miles in the Mediterranean Sea. Mediterranean Marine Science, 14: 292-294. doi: 10.12681/mms.428.

Castro, G.I., Rodríguez, M.A. \& Pérez, G.R. 2015. Effect of six different cooking techniques in the nutritional composition of two fish species previously selected as optimal for renal patient's diet. Journal of Food Science and Technology, 52: 4196-4205. doi: 10.1007/ s13197 -014-1474-8.

Castro, G.I., Ojeda, V.A., Ledesma, C.H. \& Pérez-Gil, R.F. 2007. Evaluación de los ácidos grasos n-3 de 18 especies de pescados marinos mexicanos como alimentos funcionales. Archivos Latinoamericanos de Nutrición, 57: 85-93.

Ferreira, C.E.L., Luiz, O.J., Floeter, S.R., Lucena, M.B., Barbosa, M.C., Rocha, C.R. \& Rocha, L.A. 2015. First record of invasive lionfish (Pterois volitans) for the Brazilian coast. Plos One, 10(4): e0123002. doi: 10.1371/journal.pone.0123002.

Hernández-Matus, J. \& Caballero-Vázquez, J.A. 2015. Información sobre la composición nutrimental del filete de pez león en Quintana Roo, México. In: Herrera-Martínez, G. (Ed.). Pez león: colección de recetas. Centro de Investigación Científica de Yucatán, A.C. Mérida, Yucatán, pp. 38-45.

Hoo, F.L., Johann, M.R., Grant, C. \& Buddob, D. 2013. Evaluation of dietary exposure to minerals, trace elements, and heavy metals from the muscle tissue of the lionfish Pterois volitans (Linnaeus 1758). Food and Chemical Toxicology, 60: 205-212. doi: 10.1016/ j.fct.2013.07.044.

Huss, H. 1995. Quality and quality changes on fresh fish. FAO Fisheries Technical Paper, 348: 195 pp.

Huss, H. 1999. Quality and quality changes on fresh fish. FAO Fisheries Technical Paper, 348 FAO, Rome, 206 pp. [http: www.fao.org/docrep/V7180S/V7180S00. htm]. Reviewed: April 15, 2019.

Izquierdo, C.P., Torres, F.G., González, D.E., Barboza, M.Y., Márquez, S.E. \& Cagnasso, M. 1999. Composición de ácidos grasos y contenido de humedad en doce especies de pescado de importancia comercial en Venezuela. Revista Científica de la Facultad de Ciencias Veterinarias de la Universidad de Zulia, 9: 463-468. [http://www.saber.ula.ve/handle/12345678 9/27272]. Reviewed: April 15, 2019.

Received: 6 November 2018; Accepted: 8 June 2019
Kaya, Y. \& Kocatepe, D. 2014. Chemical composition and nutritional quality of scorpionfish (Scorpaena porcus, Linnaeus 1758) muscle. Indian Journal of Animal Research, 48: 83-87. doi: 10.5958/j.0976-0555.48. 1.018 .

Morris, A. \& Akins, L. 2009. Feeding ecology of invasive lionfish (Pterois volitans) in Archipelago. Environmental Biology of Fishes, 86: 389-398. doi: 10.1007/ s10641-009-9538-8.

Morris, J.A., Thomas, A., Breen, N., Akin, L. \& Nash, B. 2011. Nutritional properties of the invasive lionfish: a delicious and nutritious approach for controlling the invasion. AACL Bioflux, 4: 21-26. [http://docs.rwu. edu/fcas_fp]. Reviewed: April 25, 2019.

Schofield, P. 2010. Update on geographic spread of invasive lionfishes (Pterois volitans [Linnaeus, 1758] and $P$. miles [Bennet, 1828] in the western North Atlantic Ocean, Caribbean Sea, and Gulf of Mexico. Aquatic Invasions Records, 5: 117-122. doi: 10.3391/ ai.2010.5.s1.024.

Tsiamis, K., Aydogan, O., Bailly, N., Balistreri, P., Bariche, M., Carden-Noad, S., Corsini-Foka, M. et al. 2015. New Mediterranean biodiversity records. Mediterranean Marine Science, 16(2): 472-488. doi: 10.12681/mms. 1440 .

U.S. Department of Health \& Human Services (U.S. DHHS) \& U.S. Department of Agriculture (USDA). 2015. Dietary guidelines for Americans 2015-2020. [http://health.gov/dietaryguidelines/2015/guidelines/]. Reviewed: March 10, 2019.

Whitfield, E., Gadner, T., Vives, S., Courtenay, M., Countenay, W., Ray, G. \& Hare, J. 2002. Biological invasion of the Indo-Pacific lionfish Pterois volitans along the Atlantic coast of North America. Marine Ecology Progress Series, 235: 289-297. doi: 10.3354/ meps 235289.

Wilcox, C.I. \& Hixon, M.A. 2015. False-positive tests for ciguatera may derail efforts to control invasive lionfish. Environmental Biology of Fishes, 98: 961969. doi: 10.1007/s10641-014-0313-0. 